\title{
Effect of fish oil and canola oil supplementation on immunological parameters, feed intake, and growth of Holstein calves
}

\author{
P. Melendez, ${ }^{1 *} \odot$ C. F. Roeschmann, ${ }^{2} \odot$ A. Baudo, ${ }^{3}$ S. Tao,,${ }^{4} \odot$ P. Pinedo, ${ }^{5} \odot$ A. Kalantari, ${ }^{1}$ M. Coarsey, ${ }^{1}$ \\ J. K. Bernard, ${ }^{6}{ }^{\oplus}$ and H. Naikare ${ }^{1}$ \\ ${ }^{1}$ College of Veterinary Medicine, University of Georgia, Athens 30602 \\ ${ }^{2}$ Faculty of Veterinary Sciences, University of Chile, Santiago, Chile \\ ${ }^{3}$ Abraham Baldwin Agricultural College, Tifton, GA 31793 \\ ${ }^{4}$ Department of Animal and Dairy Sciences, University of Georgia, Athens 30602 \\ ${ }^{5}$ Department of Animal Sciences, Colorado State University, Fort Collins 80523-1171 \\ ${ }^{6}$ Department of Animal and Dairy Sciences, University of Georgia, Tifton 31793
}

\begin{abstract}
Supplemental n-3 fatty acids (FA) may support better immune responses than n- 6 and n-9 FA in dairy calves. The objective was to evaluate the effect of n-3 FA, supplemented as a fish oil product (FO) in the milk replacer (MR), in comparison to $n-6$ and n-9 FA, supplemented as canola oil (CO), on body weight (BW), daily gain, and immunological parameters of preweaning Holstein calves. The study was conducted from September to December 2019. Calves were randomly allocated to a control group $(\mathrm{n}=15 ; \mathrm{BW}=36.2$ $\pm 1.5 \mathrm{~kg}$; mean $\pm \mathrm{SEM}$ ) supplemented daily with 30 $\mathrm{mL}$ of $\mathrm{CO}$ and to an experimental group $(\mathrm{n}=15$; $\mathrm{BW}$ $=36.3 \pm 1.5 \mathrm{~kg}$ ) supplemented with $60 \mathrm{~g}$ of a product containing $30 \mathrm{~g}$ of FO. Both treatments were added to the MR during the morning feeding. All calves were fed $4 \mathrm{~L}$ of MR at $12.5 \%$ solids at 0700 and $1600 \mathrm{~h}$ for wk $1,6 \mathrm{~L}$ from wk 2 to 7 , and $3 \mathrm{~L}$ once daily (0700 h) during wk 8 until weaning $(56 \mathrm{~d})$. Blood samples were collected at $7,14,21,28,35,42,49$, and $56 \mathrm{~d}$ of age for serum haptoglobin, TNF- $\alpha$, IL-1 $\beta$, and protectin. Dry matter intake was recorded in all experimental calves daily. Seroneutralization titers to vaccination against viral diseases (infectious bovine rhinotracheitis, parainfluenza 3 , bovine viral diarrhea, and bovine respiratory syncytial virus) were determined. Mixed models for repeated measures were developed to analyze variables over time. Seroneutralization titers were analyzed by the Kruskal-Wallis test. The other variables were compared by a generalized linear model. Serum FA profile at $35 \mathrm{~d}$ of age showed that FO supported higher concentrations of n-3 FA than CO. Final BW [65.2 vs. 62.0
\end{abstract}

Received August 9, 2021.

Accepted November 20, 2021.

*Corresponding author: pedro.melendez@ttu.edu $\mathrm{kg}$, standard error of the mean $(\mathrm{SEM})=2.1 \mathrm{~kg}]$ and average daily gain $(0.52$ vs. $0.46 \mathrm{~kg} / \mathrm{d}, \mathrm{SEM}=0.1 \mathrm{~kg} / \mathrm{d})$ tended to be higher for the FO than the CO group. An interaction of treatment $x$ day for dry matter intake was observed, especially during weaning $(2.17 \mathrm{~kg}$ vs. $1.94 \mathrm{~kg}, \mathrm{SEM}=0.158 \mathrm{~kg}$, for $\mathrm{FO}$ and $\mathrm{CO}$ group, respectively). Blood lactate (mmol/L) was higher in the $\mathrm{CO}$ than in the FO group at d 7. Haptoglobin and IL$1 \beta$ were higher for the $\mathrm{CO}$ group on d 14 than the FO group. The TNF- $\alpha$ concentrations for the FO group were reduced over time, whereas the concentrations in the CO group remained constant. Protectin was higher in the FO group on d 14, but was lower on d 28, 35, and 49. Seroneutralization antibody titers postvaccination for the $\mathrm{PI}_{3}$ virus were higher for the $\mathrm{FO}$ than the CO group. In conclusion, calves supplemented with FO had lower concentrations of blood lactate, haptoglobin, IL-1 $\beta$ and TNF- $\alpha$ than calves supplemented with CO during the study period. The FO supplementation had a higher DMI than CO supplementation. Results of this trial should be interpreted with caution due to the lack of a negative control group as well as the lower birth weight and growth rate observed under heat stress conditions.

Key words: n-3 fatty acid, fish oil, canola oil, calf, cytokine, lactate

\section{INTRODUCTION}

The preweaning period is extremely important for dairy calves due to the close relationship between growth and health during the early stages of life and forthcoming performance as a cow (Donovan et al., 1998; Godden, 2008; Van Amburgh et al., 2019). To allow for an adequate expression of the genetic potential during the productive life, early life growth should be maximized, and morbidity and mortality rates should be minimized (Godden, 2008; Gelsinger et al., 2016). 
Consequently, an adequate colostrum management, an efficient transition from monogastric to ruminant, a well-organized feed management program, adequate housing and comfort, and prevention of diseases are essential elements to consider achieving these goals (Godden, 2008; McGuirk, 2008; Khan et al., 2016). The recommended amount of milk replacer (MR) to feed varies between geographical areas in the United States (Shivley et al., 2018). Moderate feeding rates are recommended to encourage starter intake. In addition, recent studies in the southeast United States have not supported higher feeding rates $(>0.75 \mathrm{~kg} / \mathrm{d}$ of DM) during heat stress as ADG did not increase, and abomasal disorders were reported at very high rates (Orellana Rivas et al., 2020).

Lipids are carbon chain hydrophobic compounds with high energy density, which are constituents of milk and other feed sources provided to dairy calves during their first months of life (Khan et al., 2016). However, in addition to being energetic components of diet, lipids play other roles. For example, long-chain fatty acids (FA) are involved in multiple cellular functions and have received considerable attention in ruminants, especially in calves, as they are born with low reserves of these constituents (Worden et al., 2018). Within these lipids, PUFA are components of biological membranes that are involved in the transport of lipids and activity of certain lipoprotein enzymes. In addition, they are substrates for prostaglandin, prostacycline, and thromboxane syntheses, which regulate numerous cellular functions, such as blood coagulation, blood pressure, and immune responses (Calder, 2010; 2012). The $\mathrm{n}-6$ FA are long-chain PUFA with their first double bond positioned at carbon $\mathrm{n}-6$. In general, they function as proinflammatory precursors. Conversely, n-3 FA are long-chain PUFA with their first double bond positioned at carbon n-3 and serve as anti-inflammatory or proresolving inflammation precursors (Sordillo, 2016). In fact, a better recovery from inflammatory responses has been described when n-3 FA are supplemented due to the enhanced expression of lipids in bovine endothelial cells that participate in the resolution of the inflammation, such as resolvins and protectins (Contreras et al., 2012).

The n-3 FA with physiological importance are eicosapentaenoic acid (C20:5n-3; EPA) and docosahexaenoic acid (C22:6n-3; DHA). Both are metabolically related, as the initial substrate to synthesize EPA and DHA is the $\alpha$-linolenic acid. Animal tissues contain high amounts of arachidonic acid in plasma membrane phospholipids and low amounts of EPA and DHA because diets generally include higher concentrations of n- 6 and n-9 than n-3 FA. Both EPA and DHA are found in high concentrations in feeds of marine origin; consequently, fish oil (FO) is an excellent source of n-3 FA (Jin et al., 2021). This may lead to greater availability of eicosanoids with proresolving inflammatory properties (e.g. resolvins and protectins) that help in resolving inflammation (Contreras et al., 2012; Sordillo, 2016).

In fact, FO and flaxseed oil treatments in colostrum decreased isoprostane concentrations in plasma, indicating that oxidative stress was decreased (Opgenorth et al., 2020a). These authors concluded that newborn calves may benefit from n-3 FA supplementation in colostrum due to a greater anti-inflammatory state. However, in a second experiment, supplementation of n-3 FA in only one meal (colostrum) did not provide the anti-inflammatory effect observed with continuous feeding (Opgenorth et al., 2020b). Although pregnant cows fed diets high in forages may produce milk rich in n-3 FA, the concentration of EPA and DHA synthesized from $\alpha$-linolenic acid is relatively low, and calves are born with low reserves of these FA; therefore, it would be beneficial to provide EPA and DHA directly from the diet (Calder, 2017).

Hence, the hypothesis of this study was that the supplementation of a FO byproduct rich in n-3 FA (EPA and DHA) would have a greater positive effect on calf immunity than supplementation with n- 6 and n-9 FA (e.g., canola oil; CO) during the preweaning period. Consequently, the objective of this randomized controlled trial was to evaluate the effect of n-3 FA, supplemented as a FO-based product in the milk, in comparison to n- 6 and n-9 FA, supplemented as CO, on immunological parameters and growth of preweaning Holstein calves.

\section{MATERIALS AND METHODS}

\section{Farm, Animals, and Management}

All the animal-related procedures in this study were approved by the Animal Care and Use Committee of the University of Georgia (\#A2019 01-032) and funded by a USDA Animal Health Capacity Grant FY 2019. In addition, the protocol was approved under the University of Georgia NIH Animal Welfare Assurance (\#D16-00276/A3437-01).

The study was conducted at the Dairy Research Center, University of Georgia Tifton Campus, from September to December, 2019. The farm consisted of 250 Holstein lactating cows housed in a sand-bedded freestall barn equipped with fans and sprinklers to provide heat abatement. Cows were milked twice daily and fed a diet based on corn silage, grass silage, and concentrate as a TMR. Pregnant cows were dried off at 
50 to $70 \mathrm{~d}$ before expected parturition and moved to a prepartum lot $30 \mathrm{~d}$ before expected parturition. During the prepartum period, cows were fed an anionic diet to prevent hypocalcemia.

Cows delivered in the prepartum lot. The prepartum lot was monitored consistently every $2 \mathrm{~h}$ for the cows' parturition. Postnatal, calves were removed from the dam, weighed on an electronic scale, and placed in individual pens within an open-sided calf barn with a high roof and fans to improve air flow, but it was not sufficient to overcome heat stress. The navel cords of all calves were dipped with a $7 \%$ iodine solution. Calves were fed a colostrum replacer (940 g mixed with 2.77 $\mathrm{L}$ of warm water) within the first $4 \mathrm{~h}$ of life, containing a minimum of $200 \mathrm{~g}$ of $\mathrm{IgG}$ (Bovine IgG colostrum replacer; Land O'Lakes Inc.). Subsequently, calves were fed MR (17\% fat, $26 \%$ protein; Provimi North America Inc.) twice daily reconstituted to $12.5 \%$ solids. Water and a calf starter (Godfrey's Warehouse Inc.) were offered ad libitum starting at $2 \mathrm{~d}$ of life. At $7 \mathrm{~d}$ of age, calves were dehorned using a caustic paste (Dehorning paste, H. W. Naylor Company Inc.).

\section{Experimental Design}

Cows experienced heat stress ( $>70$ temperature humidity index) during the dry period, resulting in calf birth weight $<37 \mathrm{~kg}$, which is consistent with previous trials under these conditions (Monteiro et al., 2016; Orellana Rivas et al., 2020). After wk 1, calves were fed $6 \mathrm{~L}$ of MR (12.5\% solids) plus free-choice calf starter that was predicted to support an ADG between 0.5 and $0.6 \mathrm{~kg} / \mathrm{d}$ (Shivley et al., 2018). Consequently, to find a difference in $\mathrm{ADG}$ of $0.06 \mathrm{~kg} / \mathrm{d}(\mathrm{SD}=0.058$ $\mathrm{kg} / \mathrm{d})$ between the 2 treatments $(\mathrm{FO}=0.56 \mathrm{~kg} / \mathrm{d} ; \mathrm{CO}$ $=0.50 \mathrm{~kg} / \mathrm{d}$ ) with a power of $80 \%$ and a confidence of $95 \%$, a minimum sample size of 15 calves per treatment was determined (SAS 9.4). Inclusion criteria for assignment was that calves were born from an eutocic calving of clinically healthy cows with a standard dry period (50-70 d). Calves were randomly assigned to 1 of 2 treatments and matched by sex (simple randomization by flipping a coin until the same number of males and females were reached). Consequently, each treatment consisted of 15 calves ( 8 males and 7 females). One group was supplemented with $\mathrm{CO}$, and the other was supplemented with FO. Blinding was not feasible to carry out because each experimental product was added and prepared individually to each calf milk bucket and fed by the same person (a graduate student).

All calves were fed $4 \mathrm{~L}$ of MR (Provimi North America Inc.) at a dilution of $12.5 \%$ in 2 equal feedings, fed at
0700 and $1600 \mathrm{~h}$ for the first week of age. The feeding rate was increased to $6 \mathrm{~L}$ total from 2 to $7 \mathrm{wk}$ of age. The feeding rate was reduced to $3 \mathrm{~L}$ once daily $(0700 \mathrm{~h})$ during the eighth week of age. A moderate MR feeding rate was used to encourage calf starter intake based on previous research that indicated higher feeding rates did not improve ADG under heat stress conditions, and greater abomasal bloat was observed when MR feeding rate was $>0.75 \mathrm{~kg}$ of solids/d (Orellana Rivas et al., 2020). Calves were weaned at $56 \mathrm{~d}$. The FO group received $60 \mathrm{~g} / \mathrm{d}$ of a commercial product containing 30 $\mathrm{g}$ of FO (equivalent to $28 \mathrm{~mL}$ of FO; Optomega plus) added to the MR and thoroughly mixed. The CO group received $30 \mathrm{~mL} / \mathrm{d}$ of $95 \%$ pure $\mathrm{CO}$ added to the $\mathrm{MR}$ and thoroughly mixed. Treatments were fed during the morning feeding until $56 \mathrm{~d}$ of age. Calves were trained to drink from plastic buckets. If the calf did not drink from the bucket, they were fed by bottle with a nipple until they learned to drink from the buckets. The amount of residual milk was recorded daily to calculate MR consumption. The plastic buckets and bottles were washed and disinfected with a chloride solution twice daily. All calves were managed similarly.

Water was offered ad libitum from $2 \mathrm{~d}$ of age, and the buckets were washed and disinfected with a chloride solution twice daily. Calf starter was offered from $2 \mathrm{~d}$ of age, and intake was measured daily. Calves remained in the individual pens until $61 \mathrm{~d}$ of age before being transferred to a collective lot in the same barn for a 15-d transition period. Calf starter and MR samples were collected weekly and pooled for chemical analysis at Cumberland Valley Analytical Services (Table 1). All calves received a vaccine (Bovi-shield gold 5, Zoetis) at $42 \mathrm{~d}$ of age to prevent viral diseases (infectious bovine

Table 1. Chemical composition of milk replacer and calf starter fed in the trial

\begin{tabular}{lcc}
\hline $\begin{array}{l}\text { Chemical composition } \\
\text { (\% of DM) }\end{array}$ & $\begin{array}{c}\text { Milk } \\
\text { replacer }\end{array}$ & Starter \\
\hline CP & 26.55 & 17.88 \\
aNDFom & 18.53 \\
ADF & 0.15 & 18.52 \\
Starch & 0.15 & 10.22 \\
Sugar & 42.80 & 23.52 \\
Fat & 17.85 & 4.75 \\
NFC & 43.18 & 53.52 \\
Ash & 7.92 & 5.85 \\
Ca & 0.93 & 0.91 \\
P & 0.62 & 1.28 \\
Mg & 0.10 & 0.61 \\
ME $^{2}$ (Mcal/kg) & 4.80 & 2.91 \\
\hline
\end{tabular}

${ }^{1} \mathrm{NDF}$ determined using amylase and corrected for ash. ${ }^{2}$ Calculated according to NRC (2001). 
rhinotracheitis, parainfluenza 3 , bovine viral diarrhea, and bovine respiratory syncytial virus).

\section{Data and Sample Collection}

Calves were weighed at birth and at 7, 14, 21, 28, 35, 42,49 , and $56 \mathrm{~d}$ of age. Calves were clinically observed daily for diarrhea and respiratory disease, observing the preliminary respiratory rate, fecal consistency, and nasal discharges. Any calf that did not drink its allotted MR, looked depressed, had droopy ears, or laid down with the head down was evaluated for heart rate and digestive tract, and lung sounds were examined by auscultation. Rectal temperature was taken to determine the presence of fever $\left(>39.5^{\circ} \mathrm{C}\right)$. Any calf diagnosed with a digestive condition, a respiratory disease, or both was treated based upon standard operating procedures of the farm that had been outlined by the herd veterinarian. If a calf did not drink its allocated MR (either by bucket or bottle), MR was fed using an esophageal tube.

After feeding calves at $1900 \mathrm{~h}$ on d 7, 14, 21, 28, 35, 42 , and 49 , blood samples were collected via jugular venipuncture into tubes without anticoagulant (red top) for serum collection using vacutainer tubes (Becton Dickinson). Blood samples were placed on ice and transported to the Tifton Veterinary Diagnostic and Investigational Lab for centrifugation at $3,000 \times g$ for $10 \mathrm{~min}$ at $25^{\circ} \mathrm{C}$ in a clinical centrifuge (Thermo Fisher Sorvall ST 40R). Serum was separated and aliquoted for further analysis. An additional $0.1 \mathrm{~mL}$ of blood was used for lactate measurement on the same day using a clinical lactate handheld meter (StarStrip, Nova Biomedical).

Serum samples were assessed for haptoglobin (ELISA kit, Life diagnostic \# 11), protectin (CD59) (ELISA kit, Mybiosource \# MBS737067), IL-1 $\beta$ (ELISA Reagent Kit, ThermoFisher Scientific), and TNF- $\alpha$ (ELISA Reagent Kit, ThermoFisher Scientific). A seroneutralization test was conducted on samples collected on d 42, 49, and 56 to compare antibody serum titers to vaccination challenge between groups. Briefly, all sera were heat inactivated $\left(30 \mathrm{~min}\right.$ at $\left.56^{\circ} \mathrm{C}\right)$ and serially diluted, starting at 1:4 to 1:4,096 in cell-culture medium supplemented with gentamycin. Then, a virus (100-300 TCID50 per $\mathrm{mL}$ ) was added and incubated at $37^{\circ} \mathrm{C}$. After an hour of incubation, $100 \mathrm{uL}$ of MDBK cells was added, and plates were incubated at $37^{\circ} \mathrm{C}$ for 3 to $5 \mathrm{~d}$ and read for cytopathic effect of the virus. Endpoint titers were based on the last well to display complete protection against cytopathic effect. Negative and positive controls were also run, as well as a cell control and virus back titration controls, on each test to ensure testing integrity. Titers equal to or greater than
1:8 were considered antibody positive. All viruses were propagated from stocks purchased from National Veterinary Services Laboratories and confirmed by PCR.

Milk replacer, calf starter, $\mathrm{CO}, \mathrm{FO}$, and serum samples from d 35 of age were analyzed for FA profile. Approved laboratory methods were conducted by the Nutrition and Biochemistry Laboratory at the Department of Animal Sciences at Colorado State University. Fatty acid composition was obtained using gas chromatography, following methods described by Engle et al. (2000). At first, lipid extraction was performed using the method described by Folch et al. (1957). Approximately $0.25 \mathrm{~g}$ of sample homogenate was combined with $20 \mathrm{~mL}$ of chloroform:methanol solution, homogenized, and briefly filtered using Whatman no. 1 filter paper (Fisher Scientific). Then, $4 \mathrm{~mL}$ of $0.9 \% \mathrm{NaCl}$ mixture was added into $20 \mathrm{~mL}$ of chloroform:methanol solution. The final mixture was incubated at $4^{\circ} \mathrm{C}$ overnight. This process allowed the solvent to separate into 2 phases; the lower phase represented the lipid extract, which was separated and dried in a forced air-dry oven at $100^{\circ} \mathrm{C}$ for $24 \mathrm{~h}$. Following the lipid extraction, lyophilization was performed by using a methylated solution of $1 \mathrm{~mL}$ of $0.5 \mathrm{~N} \mathrm{KOH}$ in methanol, and then heated in a water bath for $2 \mathrm{~h}$. Samples were then prepared for gas chromatography by mixing with $2 \mathrm{~mL}$ of HPLC-grade hexane and $2 \mathrm{~mL}$ of saturated $\mathrm{NaCl}$. This mixture was then re-extracted and reconstituted to concentrate the FA. The reconstituted lipid was measured by gas chromatography (Claurus 590, Perkin Elmer) fitted with a fused carbon wax column $(30 \mathrm{~m} \times 0.32 \mathrm{~mm}$ i.d., 0.25 $\mu \mathrm{m}$ film thickness) and flame ionization detector. The following instrument parameters were used: injection mode $=$ split less; injection volume $=1.0 \mu \mathrm{L}$; carrier gas = helium; carrier gas flow $=1.0 \mathrm{~mL} / \mathrm{min}$; injector temperature $=200^{\circ} \mathrm{C}$; oven ramping program $=100^{\circ} \mathrm{C}$ for $15 \mathrm{~min}, 185^{\circ} \mathrm{C}$ for $15 \mathrm{~min}$; detector temperature = $215^{\circ} \mathrm{C}$. Standard FA methyl ester mixtures were run in addition to the SUPELCO FA methyl ester standard (Millipore Sigma). Final FA profiles were identified by matching respective peak retention times to those of standards and calculating as normalized area percentages of FA. Colostrum management was monitored by measuring serum total proteins $(\mathbf{S T P} ; \mathrm{g} / \mathrm{dL})$ at $\mathrm{d} 7$ (Godden, 2008) using a clinical refractometer (Reichert Technologies r2i300).

\section{Statistical Analysis}

Comparisons of DMI, blood cytokines, lactate, and haptoglobin over time between the 2 groups were evaluated using a repeated measures mixed model ANOVA with calf as a random effect nested within treatment. The model was defined as follows: 


$$
\begin{aligned}
\mathrm{Y}_{\mathrm{ijklmn}}=\mu+ & \mathrm{T}_{\mathrm{i}}+\text { Gen }_{\mathrm{j}}+\text { Calf }_{\mathrm{k}}\left(\mathrm{T}_{\mathrm{i}}\right)+\mathrm{TP}_{1}+\text { Day }_{\mathrm{m}} \\
& +\left(\mathrm{T} \times \text { Day }_{\mathrm{im}}+\mathrm{e}_{\mathrm{ijklmn}},\right.
\end{aligned}
$$

where $\mathrm{Y}_{\mathrm{ijklmn}}=$ dependent variable (DMI, metabolites), $\mu=$ overall population mean, $T_{i}=$ effect of treatment $(\mathrm{CO}, \mathrm{FO}), \mathrm{Gen}_{\mathrm{j}}=$ effect of sex (male, female), Calf $_{\mathrm{k}}\left(\mathrm{T}_{\mathrm{i}}\right)$ $=$ random effect of calf nested within treatment, $\mathrm{TP}_{1}=$ effect of STP $(\mathrm{g} / \mathrm{dL})$, Day $_{\mathrm{m}}=$ effect of sampling day, $(\mathrm{T}$ $\times$ Day $_{\text {im }}=$ interaction of treatment by sampling day, $\mathrm{e}_{\mathrm{ijklmn}}=$ error term.

The treatment by day interaction was the most important effect of the model because it determined the parallelism of the curves between both treatments. For all models, the best goodness of fit was specified according to the Schwarz's Bayesian Criterion (Littell et al., 1998). Body weight at weaning, ADG, and feed efficiency were analyzed by general linear model (PROC GLM, SAS 9.4) that included effects of treatment, sex, $\mathrm{TP}$, and initial BW in the full model. Least squares means \pm standard error of the mean were reported. Significance was declared when $P \leq 0.05$, and tendency was considered $0.05 \leq P \leq 0.1$. Seroneutralization antibody titers to vaccination were analyzed using the Kruskal-Wallis test. Median scores were reported. Statistical analyses were conducted using SAS 9.4.

\section{RESULTS}

\section{Fatty Acid Profiles}

The FA profiles of calf starter, MR, and $\mathrm{CO}$ and FO supplements are presented in Table 2. The serum FA profile at $35 \mathrm{~d}$ of age for the $\mathrm{CO}$ and $\mathrm{FO}$ groups are presented in Table 3. Overall, the FO group had a higher serum concentration of n-3 FA than the $\mathrm{CO}$ group $(P \leq 0.05)$. Total saturated FA concentrations tended to be higher $(P=0.10)$ for the CO group than the FO group. In addition, the sum of n- 6 and n-9 FA were not different between treatments $(P=0.20)$.

\section{Dry Matter Intake and Body Weight}

Concentrations of STP at $7 \mathrm{~d}$ of age, average daily DMI (MR plus calf starter), initial and final BW, and feed efficiency (FE) are presented in Table 4. The STP and initial BW were not different $(P>0.05)$ between treatments. However, final BW $(P=0.08)$ and ADG $(P$ $=0.09)$ tended to be higher for the FO group compared with the CO group. Feed efficiency was not different $(P$ $=0.35$ ) between treatments. An interaction of treatment $\times$ day $(P=0.019)$ was observed for DMI due to higher intake for the FO group than the CO group during the last $10 \mathrm{~d}$ of the rearing period (Figure 1).

\section{Immune and Health Parameters}

There were no cases of respiratory diseases or mortalities during the study; however, there was a tendency for a higher incidence of diarrhea for CO group (86.7\%, $13 / 15)$ than in the FO $(60 \%, 9 / 15 ; P=0.10)$. Calves with diarrhea were treated with oral electrolytes, nonsteroidal anti-inflammatories, and antibiotics. All animals were recovered after the treatment protocol.

There was no interaction of treatment $x$ day in blood lactate concentrations (mmol/L; $P>0.05)$; however, the concentration of blood lactate was higher $(P \leq$ $0.05)$ on $\mathrm{d} 7$ and tended to be higher on d $28(P \leq 0.1)$ for the CO group compared with the FO group (Figure 2).

No differences $(P>0.05)$ between treatments or an interaction of treatment $x$ day were observed in serum haptoglobin concentrations (Figure 3a). However, hap-

Table 2. Fatty acid (FA) profile of milk replacer, calf starter, canola

\begin{tabular}{|c|c|c|c|c|}
\hline \multirow[b]{2}{*}{ Fatty acid } & \multicolumn{4}{|c|}{ Fatty acid, g/100 g of total FA } \\
\hline & $\begin{array}{c}\text { Canola } \\
\text { oil }\end{array}$ & $\begin{array}{c}\text { Fish } \\
\text { oil }\end{array}$ & $\begin{array}{l}\text { Milk } \\
\text { replacer }\end{array}$ & $\begin{array}{c}\text { Calf } \\
\text { starter }\end{array}$ \\
\hline $\mathrm{C} 4: 0$ & 0.01 & 0 & 0 & 0 \\
\hline $\mathrm{C} 6: 0$ & 0.09 & 0 & 0 & 0 \\
\hline $\mathrm{C} 8: 0$ & 0.765 & 0.02 & 0.85 & 0 \\
\hline C10:0 & 0.28 & 0.11 & 7.06 & 0.015 \\
\hline C11:00 & 0.075 & 0.395 & 0.2 & 0 \\
\hline C12:0 & 0.24 & 0.595 & 25.26 & 0.105 \\
\hline C13:0 & 0.05 & 0.405 & 0.38 & 0.01 \\
\hline $\mathrm{C} 14: 0$ & 1.555 & 0.045 & 43.96 & 0.985 \\
\hline $\mathrm{C} 14: 1$ & 0.04 & 0.345 & 2.64 & 0.12 \\
\hline C15:0 & 0.57 & 5.98 & 3.69 & 0.32 \\
\hline C15:1 & 0.15 & 0.065 & 0.16 & 0.02 \\
\hline C16:0 & 17.28 & 9.88 & 43.36 & 38.665 \\
\hline C16:1 & 6.41 & 6.245 & 1.27 & 2.1 \\
\hline C17:0 & 1.17 & 5.155 & 2.92 & 0.45 \\
\hline C17:1 & 1.265 & 2.48 & 0.83 & 0.26 \\
\hline C18:0 & 2.955 & 0.035 & 8.27 & 0.005 \\
\hline C18:1 & 8.92 & 3.18 & 44.2 & 25.855 \\
\hline $\mathrm{C} 18: 2 \mathrm{n}-6 \mathrm{cis}$ & 0 & 0 & 0.08 & 0 \\
\hline $\mathrm{C} 18: 2 \mathrm{n}-6$ trans & 1.03 & 0 & 0 & 0 \\
\hline C18:3n-6 & 0.35 & 0.86 & 0.26 & 0.085 \\
\hline C18:3n-3 & 9.265 & 0.265 & 0.63 & 20.635 \\
\hline C20:0 & 2.805 & 5.01 & 1.68 & 1.96 \\
\hline C20:1 & 7.275 & 28.415 & 3.55 & 4.065 \\
\hline $\mathrm{C} 20: 2$ & 2.195 & 0.285 & 1.86 & 0.27 \\
\hline C20:3n-6 & 0 & 0.86 & 0.94 & 0 \\
\hline $\mathrm{C} 21: 0$ & 0.64 & 0 & 0.14 & 0.105 \\
\hline $\mathrm{C} 20: 3 \mathrm{n}-3$ & 0.38 & 3.255 & 2.48 & 0.035 \\
\hline $\mathrm{C} 20: 4 n-6$ & 1.005 & 1.79 & 0.44 & 0.06 \\
\hline C20:5n-3 & 1.57 & 7.71 & 0.45 & 0.5 \\
\hline $\mathrm{C} 22: 0$ & 10.05 & 2.595 & 0.82 & 1.295 \\
\hline $\mathrm{C} 22: 1 \mathrm{n}-9$ & 10.83 & 9.93 & 0.23 & 0.395 \\
\hline $\mathrm{C} 22: 2$ & 0.835 & 0.935 & 0.67 & 0.17 \\
\hline C23:0 & 1.025 & 0.035 & 0.36 & 0.305 \\
\hline C24:0 & 6.23 & 3.11 & 0.39 & 0.935 \\
\hline C22:6n-3 & 2.14 & 0 & 0 & 0 \\
\hline C24:1n-9 & 0.525 & 0 & 0 & 0.285 \\
\hline
\end{tabular}
oil, and fish oil supplement 
toglobin concentration was significantly lower in the FO group than the $\mathrm{CO}$ group at d $14(P \leq 0.05)$. The opposite was found at d $49(P \leq 0.05)$. Concentrations of serum IL-1 $\beta$ were not different between groups (Figure $3 \mathrm{~b})$. An interaction of treatment $\times$ day $(P \leq 0.05)$ and day effect $(P \leq 0.05)$ was observed for serum TNF- $\alpha$ concentrations (Figure 3c). Concentrations of TNF- $\alpha$ declined with FO, whereas no change was observed for the $\mathrm{CO}$ group, which remained steady through the trial. No differences $(P>0.05)$ were observed in serum protectin (CD59) concentrations (Figure 3d) among treatment or interaction treatment $\times$ day. Figure 4 presents seroneutralization antibody titers to vaccination, which were higher $(P \leq 0.05)$ for the $\mathrm{PI}_{3}$ virus on $\mathrm{d} 49$ and $\mathrm{d}$ 56 for the FO group compared with the CO group.

Table 3. Serum fatty acid (FA) profile of calves fed milk replacer supplemented with either canola oil $(\mathrm{CO}, \mathrm{n}=15)$ or fish oil $(\mathrm{FO}, \mathrm{n}=$ 15) at $35 \mathrm{~d}$ of age

\begin{tabular}{|c|c|c|c|c|}
\hline \multirow[b]{2}{*}{ Fatty acid } & \multicolumn{4}{|c|}{ Fatty acid, g/100 g of total FA } \\
\hline & $\mathrm{CO}$ & $\mathrm{FO}$ & SEM & $P$-value \\
\hline C4:0 & 0 & 0.001 & 0.0006 & 0.35 \\
\hline C6:0 & 0.095 & 0.003 & 0.044 & 0.31 \\
\hline C8:0 & 0.006 & 0.028 & 0.011 & 0.32 \\
\hline C10:0 & 0.0021 & 0 & 0.001 & 0.29 \\
\hline C11:00 & 0 & 0 & 0 & - \\
\hline C12:0 & 0.44 & 0.34 & 0.07 & 0.49 \\
\hline C13:0 & 0.013 & 0.011 & 0.003 & 0.80 \\
\hline C14:0 & 2.44 & 2.44 & 0.11 & 0.97 \\
\hline C14:1 & 0.14 & 0.15 & 0.028 & 0.84 \\
\hline C15:0 & 0.60 & 0.60 & 0.02 & 1.0 \\
\hline C15:1 & 0.99 & 1.03 & 0.20 & 0.90 \\
\hline C16:0 & 32.9 & 32.2 & 0.53 & 0.52 \\
\hline C16:1 & 2.16 & 2.35 & 0.10 & 0.32 \\
\hline C17:0 & 0.62 & 0.63 & 0.02 & 0.68 \\
\hline C17:1 & 0.28 & 0.20 & 0.02 & 0.04 \\
\hline C18:0 & 19.5 & 17.8 & 0.43 & 0.05 \\
\hline C18:1 & 23.5 & 23.1 & 0.59 & 0.74 \\
\hline $\mathrm{C} 18: 2 \mathrm{n}-6$ cis & 10.5 & 13.3 & 0.94 & 0.14 \\
\hline $\mathrm{C} 18: 2 \mathrm{n}-6$ trans & 0 & 0 & 0 & - \\
\hline C18:3n-6 & 0.19 & 0.21 & 0.024 & 0.64 \\
\hline C18:3n-3 & 0.27 & 0.34 & 0.037 & 0.37 \\
\hline $\mathrm{C} 20: 0$ & 0.42 & 0.35 & 0.03 & 0.31 \\
\hline C20:1n-9 & 1.45 & 1.28 & 0.07 & 0.22 \\
\hline C20:2 & 0.12 & 0.14 & 0.013 & 0.68 \\
\hline C20:3n-6 & 0.09 & 0.21 & 0.02 & 0.01 \\
\hline C21:0 & 0.10 & 0.06 & 0.009 & 0.07 \\
\hline C20:3n-3 & 0.19 & 0.62 & 0.10 & 0.04 \\
\hline C20:4n-6 & 0.11 & 0 & 0.05 & 0.29 \\
\hline $\mathrm{C} 20: 5 \mathrm{n}-3$ & 0.02 & 0.24 & 0.06 & 0.10 \\
\hline C22:0 & 0.54 & 0.54 & 0.05 & 0.98 \\
\hline C22:1n-9 & 0.47 & 0.40 & 0.14 & 0.80 \\
\hline $\mathrm{C} 22: 2$ & 1.13 & 0.68 & 0.22 & 0.34 \\
\hline $\mathrm{C} 23: 0$ & 0.27 & 0.15 & 0.037 & 0.10 \\
\hline C24:0 & 0.30 & 0.29 & 0.018 & 0.79 \\
\hline C22:6n-3 & 0 & 0.05 & 0.019 & 0.19 \\
\hline C24:1n-9 & 0.01 & 0.05 & 0.016 & 0.23 \\
\hline n-3 FA & 0.489 & 1.261 & 0.09 & 0.05 \\
\hline $\mathrm{n}-6+\mathrm{n}-9$ FA & 12.83 & 15.48 & 1.35 & 0.20 \\
\hline Total saturated FA & 58.28 & 55.53 & 1.24 & 0.10 \\
\hline
\end{tabular}

Table 4. Dry matter intake, initial and final BW, ADG, and feed efficiency (FE) of calves fed supplemental canola oil ( $\mathrm{CO}$ ) and fish oil (FO)

\begin{tabular}{lcccc}
\hline Item & $\begin{array}{c}\mathrm{CO} \\
(\mathrm{n}=15)\end{array}$ & $\begin{array}{c}\mathrm{FO} \\
(\mathrm{n}=15)\end{array}$ & SEM & $P$-value \\
\hline $\mathrm{STP},{ }^{1} \mathrm{~g} / \mathrm{dL}$ & 5.30 & 5.53 & 0.65 & 0.67 \\
$\mathrm{DMI}, \mathrm{kg} / \mathrm{d}$ & 0.75 & 0.80 & 0.04 & 0.25 \\
Initial BW, kg & 36.2 & 36.3 & 1.5 & 0.95 \\
Final BW, $\mathrm{kg}$ & 62.0 & 65.2 & 2.1 & 0.08 \\
$\mathrm{ADG}, 0-60 \mathrm{~d}, \mathrm{~kg} / \mathrm{d}$ & 0.46 & 0.52 & 0.1 & 0.09 \\
$\mathrm{FE},{ }^{3} 0-60 \mathrm{~d}$ & 0.61 & 0.65 & 0.03 & 0.35 \\
\hline
\end{tabular}

${ }^{1}$ Serum total proteins.

${ }^{2}$ Average DMI from d 3 to 60 (milk replacer plus calf starter).

${ }^{3}$ Feed efficiency calculated as ADG/DMI, kilograms of BW gain for each kilogram of DMI.

\section{DISCUSSION}

The hypothesis of the study was that Holstein calves fed $30 \mathrm{~g} / \mathrm{d}$ (equivalent to $28 \mathrm{~mL}$ of $\mathrm{FO}$ ) of supplemental FO in the MR would have improved immunological responses, resulting in the potential for improved growth, as compared with calves supplemented with $30 \mathrm{~mL}$ of CO. This hypothesis is partially accepted because FO improved DMI during the last $10 \mathrm{~d}$ of the rearing period and modulated inflammatory mediators, supporting a tendency for a greater BW at weaning compared with the $\mathrm{CO}$ group (3.2 $\mathrm{kg}$ difference). Both group diets were isonitrogenous, isoenergetic, and isolipidic. However, FO supported an ADG of $0.52 \mathrm{~kg} / \mathrm{d}$ compared with $0.49 \mathrm{~kg} / \mathrm{d}$ for $\mathrm{CO}$, which is acceptable for preweaning dairy calves, although neither treatment doubled their birth weight at weaning. Under heat stress conditions that are typical for Georgia, ADG is lower compared with calves reared under nonheat stress conditions (Tao et al., 2012; Dahl et al., 2016; Orellana Rivas et al., 2020; Wang et al., 2020). Calves in the current study were housed in a barn equipped with fans to improve air flow, but it was not sufficient to overcome the negative effects of heat stress, which are common environmental conditions in subtropical and tropical climates.

In a meta-analysis study, Gelsinger et al. (2016) reported that calves gaining weight above $0.5 \mathrm{~kg} / \mathrm{d}$ can enhance their first lactation performance when preweaning management is combined with good practices after weaning. Average daily gain and weaning weight are multifactorial in nature. Undoubtedly, higher DMI is one of the most important variables accounting for BW at weaning. However, both FE and health status have also been reported to directly affect ADG independent of DMI (Gelsinger et al., 2016).

There are few studies evaluating FO or other n-3 FA based products on preweaning calf performance. In studies where linseed oil products were fed as a source 
of n-3 FA, ADG between 0.68 and $0.72 \mathrm{~kg} / \mathrm{d}$ were reported; however, calves were 2 to $3 \mathrm{~kg}$ heavier at birth than the calves in our current investigation (Hill et al., 2011; Karcher et al., 2014; Melendez et al., 2020) and were not reared under heat stress conditions. In our study, the calves averaged only $36 \mathrm{~kg}$ at birth, which was lower compared with other trials. This low birth weight was due to the negative effect of heat stress that late-gestation cows experienced during July and August. In fact, cows during the early dry and prepartum periods had shade but did not have access to evaporative cooling system to abate the negative effect of heat stress. In addition, southeast states (FL, GA) normally have a THI $>77$ during summertime, which is considered the cut-off for severe heat stress (Peña et al., 2016). When cooling is not provided during the dry period, the cow gives birth to a lighter weight calf (Tao et al., 2012; Dahl et al., 2016; Orellana Rivas et al., 2020). In fact, calves born to cows without a cooling system weighed $6 \mathrm{~kg}$ less $(36.5 \mathrm{~kg}$ ) than calves born from cows with a cooling system $(42.5 \mathrm{~kg})$. In our current study, both groups of calves had the same weight at birth, which supports that those calves were properly randomized to treatments.

A weakness of our study was the lack of a negative control group without oil supplementation. This did not allow us to evaluate the potential positive effect of supplementing calves with CO. Previous research suggests that calves have higher ADG when the diet is enriched with CO compared with a negative control. Hill et al. (2007) reported higher ADG with CO supplementation compared without supplementation $(0.61 \mathrm{~kg} / \mathrm{d}$ vs. $0.51 \mathrm{~kg} / \mathrm{d}$, respectively). The lack of a negative control in the trial was due to several reasons as follows: (1) there were budget constraints, (2) there were no more calves available for a third group because of the projected number of parturitions in that season, and (3) the design of the experiment considered the comparison of groups with the same fat content of the diet. Consequently, the results from our study did not allow us to make any conclusions related to performance without supplemental oil under heat stress conditions. The explanatory variables for weaning weight and ADG in the statistical model were the birth weight, STP, sex of the calf, and treatment effect. The $\mathrm{R}^{2}$ of the model was 0.38 , meaning that the model only explained $38 \%$ of the variance in weaning BW, whereas other potential confounders were not identified, such as external environmental factors and the negative effect of heat stress that could have contributed to lower ADG in both treatments.

Focusing on immune parameters, in a study conducted in Poland observed the effect of supplemental DHA-rich algae in MR on performance and immune responses (Flaga et al., 2019). In general, supplementation of $9 \mathrm{~g}$ of DHA-rich algae improved ADG and FE, but growth variables decreased when the dose increased to 18 and $27 \mathrm{~g} / \mathrm{d}$. These researchers also reported that MR and calf starter intake linearly decreased with increasing DHA-rich algae compared with the control. Algae product was added to the MR; therefore, a negative effect on milk palatability must not be ruled

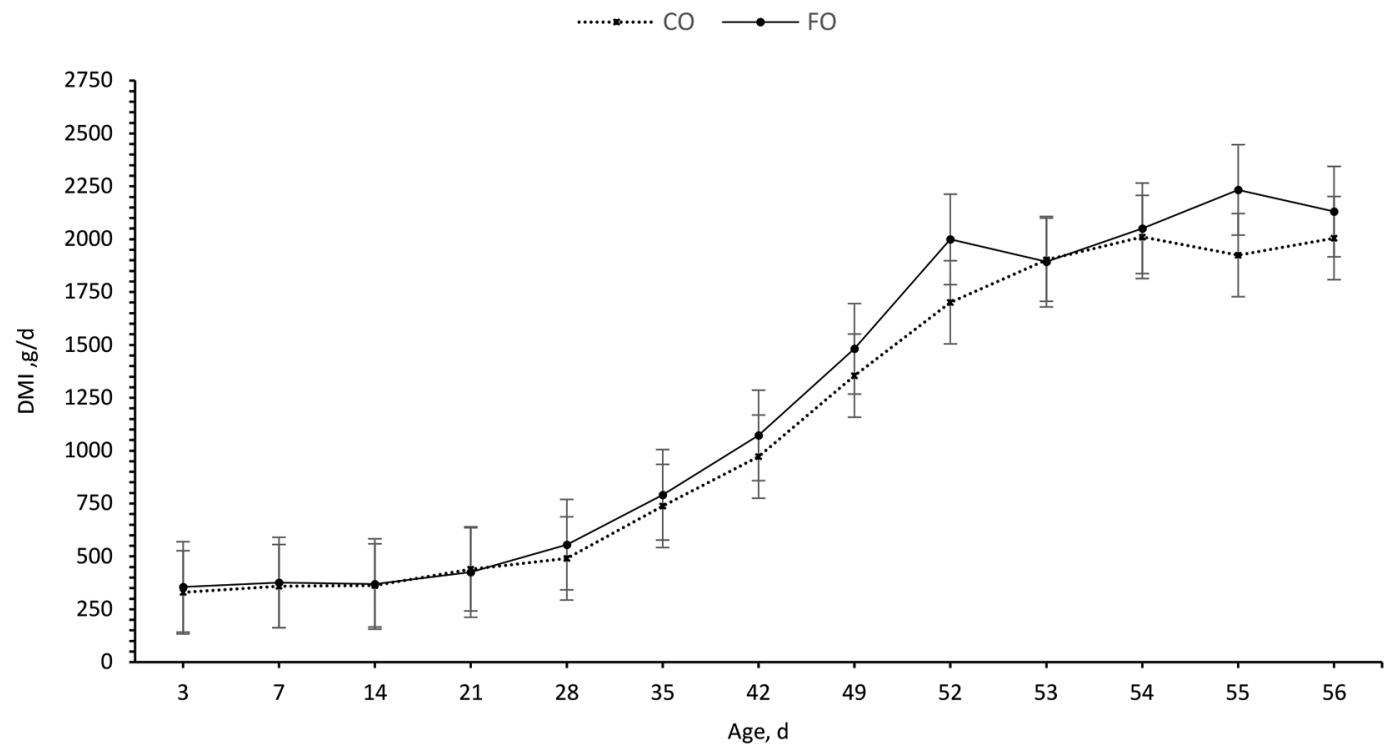

Figure 1. Dry matter intake (g/d of milk replacer plus calf starter) for calves fed supplemental canola oil (CO) or fish oil (FO). There was an interaction of treatment $\times$ day $(P=0.019)$. The DMI was higher for FO compared with $\mathrm{CO}$ on $\mathrm{d} 45(P=0.02), 47(P=0.13), 52(P=$ $0.005)$, and $55(P=0.003)$. Bars represent SEM. 


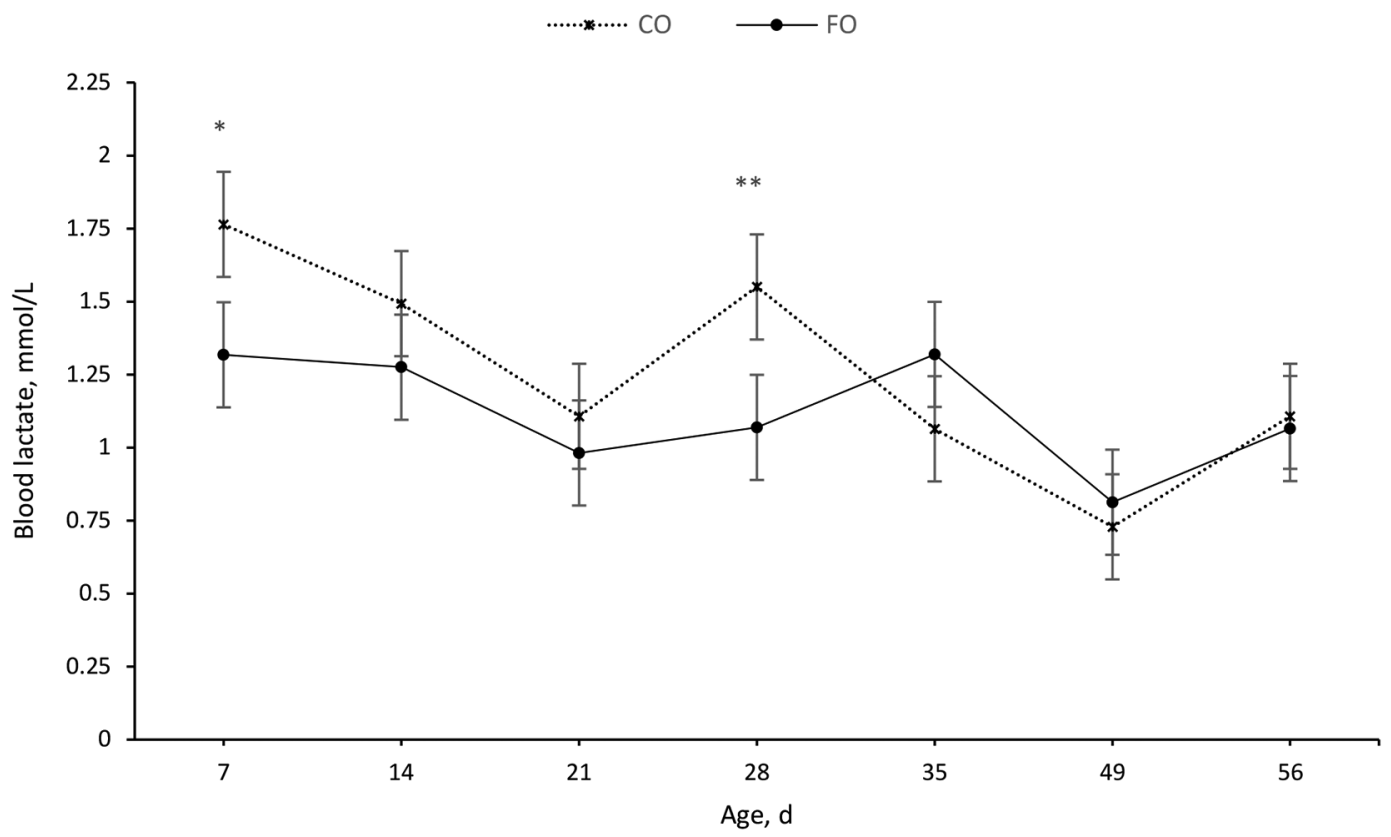

Figure 2. Blood lactate concentrations (mmol/L) in calves fed supplemental canola oil (CO) or fish oil (FO). There was no interaction of treatment $\times$ day $(P>0.05) .{ }^{*} P \leq 0.05 ; * * P \leq 0.1$. Bars represent SEM.

out. However, mRNA expression of IL-1 $\beta$, TNF- $\alpha$ and nuclear factor- $\kappa \mathrm{B}$ p65 subunit were decreased linearly with increasing DHA-rich algae supplementation. Consequently, the authors concluded that although algae product decreased growth, perhaps due to palatability issues of the supplement, beneficial effects on immunological variables were observed. In our current study, the consumption of MR plus calf starter were higher for the FO group than the $\mathrm{CO}$ group. Unlike the Polish study, in our investigation, one group was supplemented with $\mathrm{CO}$ and the other with a FO-based product to ensure that diets were isonitrogenous, isoenergetic, and isolipidic. However, the palatability aspect of the oils could have had a different effect in both treatments. The total amount of FA reaching the duodenum might be similar, thus the cholecystokinin secretion would have been the same, with comparable results on appetite regulation (Flaga et al., 2019). Therefore, although FO may have lower palatability than other oil sources, in our study, the higher DMI observed for FO group might be explained more rationally by the effect of the n-3 FA on the immunological responses of the calves rather than any differences in dietary energy concentrations or palatability issues.

Colostrum, calf management, and STP were similar for the calves enrolled in both the $\mathrm{CO}$ and $\mathrm{FO}$ groups $(5.30$ vs. $5.53 \pm 0.65 \mathrm{~g} / \mathrm{dL}$, respectively; $P>0.05)$. All calves received the same dose and quality of colostrum. In addition, calves were born from an eutocic parturition and were alert, standing, and had normal behavior when they received colostrum and started the trial. Unfortunately, it was not feasible to obtain a blood sample at d 1 of age due to farm logistics, especially with calves born at night. Although we acknowledge this issue as a drawback for baseline comparisons, we suggest that the effect of treatment on immunological parameters might be minimal during the first week of life, unlike lactate, which is an objective indicator for metabolic acidosis (Omole et al., 2001).

Calves fed supplemental FO had lower blood lactate concentrations during the first $4 \mathrm{wk}$ of life compared with the $\mathrm{CO}$ group. High blood lactate can be considered a more objective physiological parameter for subclinical digestive disorders. In fact, the $\mathrm{CO}$ group tended to have higher incidence of diarrhea than the FO group, and lactic acidosis is very common in diarrheic calves (Omole et al., 2001). Interestingly, although there was no interaction for treatment $\times$ day, the $\mathrm{CO}$ group had increased levels of haptoglobin and IL-1 $\beta$ in addition to lactate in specific days (LSM pairwise comparison), contrasting with the FO group. This reported difference may indicate that $\mathrm{CO}$ supported a more proinflammatory state during the first month of life than FO. In addition, CO maintained steady TNF- $\alpha$ concentrations compared with $\mathrm{FO}$, which was observed to have a consistent decrease in $\mathrm{TNF}-\alpha$ concentrations from birth to weaning. Furthermore, $\mathrm{CO}$ was observed to support higher concentrations of protectin than FO beyond $3 \mathrm{wk}$ of age, indicating they were in an active resolution of inflammatory processes (Sordillo, 2016). 
(A)

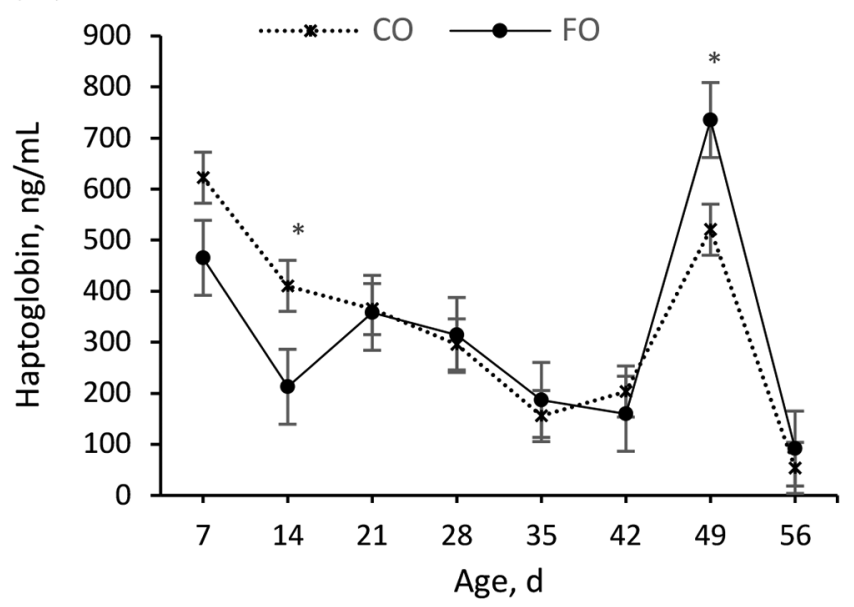

(C)

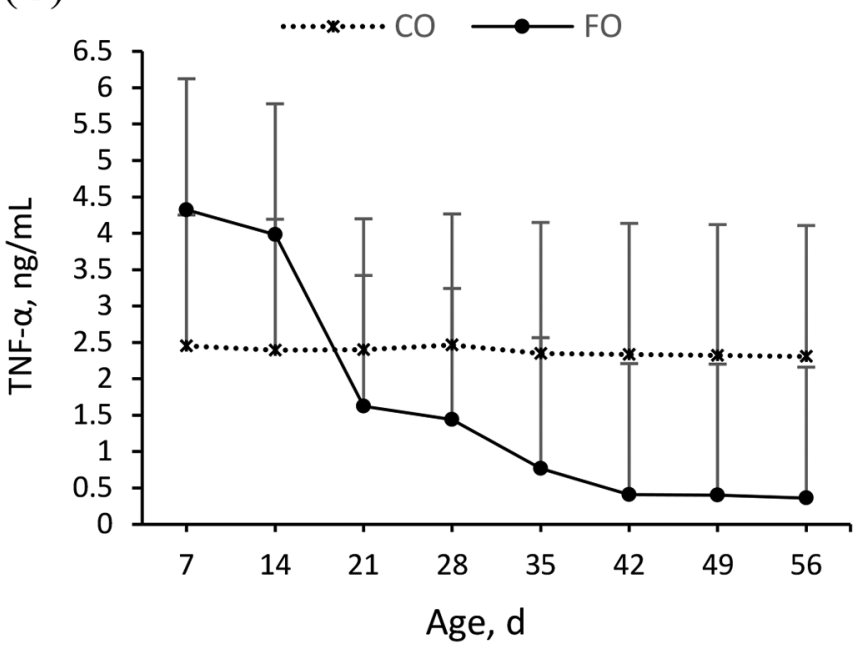

(B)

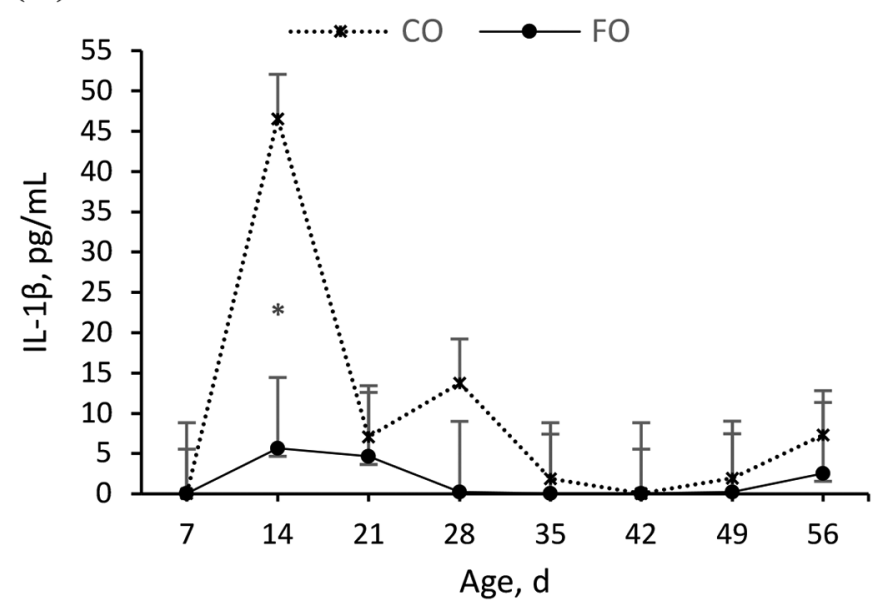

(D)

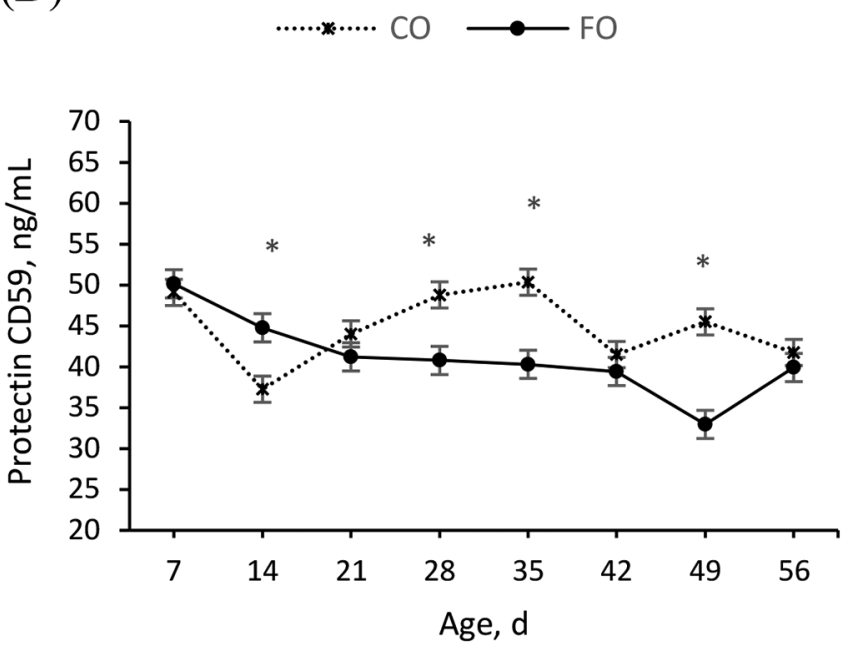

Figure 3. (A) Haptoglobin concentrations $(\mathrm{ng} / \mathrm{mL})$ in calves fed supplemental canola oil (CO) or fish oil (FO). There was no interaction of treatment $\times$ day $(P>0.05)$. (B) Interleukin-1 $\beta$ concentrations $(\mathrm{pg} / \mathrm{mL})$ of calves fed diets supplemented with CO or FO. There was no interaction of treatment $\times$ day $(P>0.05)$. There was a day effect $(P \leq 0.05)$. (C) Tumor necrosis factor $\alpha(\mathrm{ng} / \mathrm{mL})$ concentrations of calves fed diets supplemented with CO or FO. There was an interaction of treatment $\times$ day $(P \leq 0.05)$ and day effect $(P \leq 0.05)$. (D) Protectin $($ CD59) concentrations $(\mathrm{ng} / \mathrm{mL})$ of calves fed diets supplemented with $\mathrm{CO}$ or FO. There was no interaction of treatment $\times$ day $(P>0.05)$. ${ }^{*} P \leq 0.05$. Bars represent SEM.

Other trials in which fish or flaxseed oil was supplemented to colostrum reported inconclusive results on immune responses (Opgenorth et al., 2020a,b), most likely because the supplement was only fed once rather than continuously during the entire milk-feeding period such as in our study.

Contrary to our current results, a recent study indicated that calves fed a linseed oil byproduct had higher concentrations of haptoglobin at $7 \mathrm{~d}$ of age (Melendez et al., 2020). A potential explanation for these divergences might be related to the higher incidence of scours experienced by the linseed group compared with controls (canola meal) during the first $2 \mathrm{wk}$ of life. Certainly, diarrhea could trigger a stronger inflamma- tory response from the intestine, reflected by high concentrations of haptoglobin on d 7 and a trend for high concentrations of IL-1 at $21 \mathrm{~d}$ of age. Calves developing respiratory diseases and digestive conditions during the first week of life respond with fever, depression, and high concentrations of haptoglobin (Murray et al., 2014). Haptoglobin is an acute-phase protein produced predominantly by the liver in response to a bacteria or viral infection, which tightly binds hemoglobin during hemolysis. The hemoglobin-haptoglobin complex reduces oxidative properties of the heme group, providing protection against the toxic properties of hemoglobin. In addition, haptoglobin concentrations increase substantially during acute inflammation (Andersen et al., 


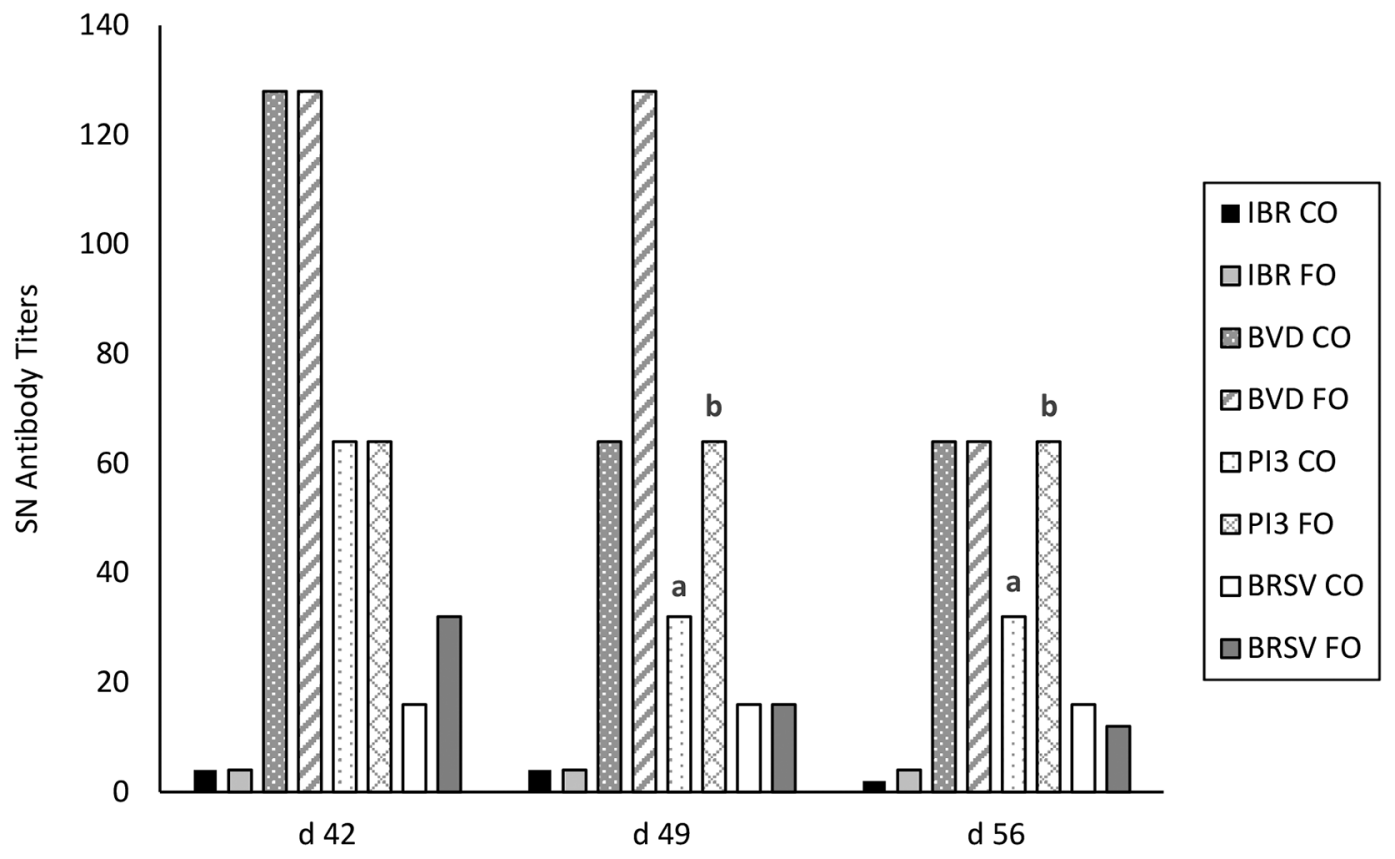

Figure 4. Seroneutralization (SN) vaccine antibody titers in calves fed diets supplemented with canola oil (CO) or fish oil (FO). Means with different letters $(\mathrm{a}, \mathrm{b})$ differ $(P \leq 0.05)$. IBR = infectious bovine rhinotracheitis; PI3 = parainfluenza 3 ; BVD = bovine viral diarrhea; BRSV $=$ bovine respiratory syncytial virus.

2017). After endotoxin release from the intestine into the blood circulation, the release of proinflammatory cytokines, such as IL-1, IL-6 and TNF- $\alpha$, by immune cells results in acute-phase protein secretion from the liver (Dong et al., 2011). In calves and adult cattle, disease has been linked with a significant rise in serum haptoglobin concentrations, which can be used as biomarker for inflammatory conditions in cattle (Gånheim et al., 2007; Eckersall and Bell, 2010). Consequently, in the present study, we may suggest that calves fed $\mathrm{CO}$ were in a more proinflammatory state during the first 2 wk of age than those fed supplemental FO, which is also corroborated by the higher concentrations of IL-1 $\beta$ and lactate. It is possible that n-3 FA from FO induced a more anti-inflammatory effect or better resolution of any potential inflammatory response than the $\mathrm{CO}$ supplementation. In fact, serum n-3 FA concentrations were higher at d 35 in calves supplemented with FO compared with $\mathrm{CO}$, reflecting the effect of FO supplementation. In the study by Melendez et al. (2020), concentrations of resolvin-E1 were higher for calves supplemented with linseed oil compared with those fed supplemental canola meal, suggesting that calves fed the linseed-based starter, another feed source rich in n-3 FA, had a better response to the digestive inflammatory process. Therefore, these calves had a potentially shorter and more efficient recovery than the calves affected with diarrhea in the canola group; consequently, the growth was similar between both groups. In another study, Ballou and DePeters (2008) supplemented Jersey calves with FO in the MR; however, they did not provide calf starter during the entire period. They reported several positive immune responses; however, neither growth parameters nor health performance were different compared with the control group supplemented with CO.

The higher titers of antibodies against the $\mathrm{PI}_{3}$ virus may suggest that the immunological dynamic to vaccination in the $\mathrm{FO}$ group was better than the $\mathrm{CO}$ group, perhaps due to a better health status resulting from a lower proinflammatory stage and higher consumption of DMI, which may have determined a better response to vaccination. In fact, clinical trials highlight the importance of supplementing vitamins A, C, and $\mathrm{D}$; n-3 FA; and zinc to positively modulate the immune response against respiratory viral infections (Pecora et al., 2020). Higher DMI during the second month of life likely increased the amount of nutrients received by the FO group, including the amount of n-3 FA, potentially improving the response to vaccination against viral diseases.

Overall, studies that consider the supplementation of n-3 FA (e.g., fish and flaxseed oil) in young dairy calves mainly report positive effects on calf immunity rather than on growth and performance characteristics. Consequently, the results of the present trial suggest 
that calves fed supplemental FO had lower blood lactate, serum haptoglobin, IL- $1 \beta$, and TNF- $\alpha$ concentrations compared with those fed supplemental CO. These immunological changes may support higher DMI compared with the $\mathrm{CO}$ group. However, the lack of a negative control group and low birth weight and ADG observed for both treatments during the entire study makes it difficult to determine how these results would compare without supplemental oil or be extrapolated to the normal population of US dairy calves; therefore, the result of the present investigation must be interpreted with caution.

\section{ACKNOWLEDGMENTS}

The authors thank the USDA Animal Health Capacity Grant FY 2019 for funding this study through the University of Georgia, Athens. The authors have not stated any conflicts of interest.

\section{REFERENCES}

Andersen, C. B. F., K. Stødkilde, K. L. Sæderup, A. Kuhlee, S. Raunser, J. H. Graversen, and S. K. Moestrup. 2017. Haptoglobin. Antioxid. Redox Signal. 26:814-831. https://doi.org/10.1089/ars.2016 .6793 .

Ballou, M. A., and E. J. DePeters. 2008. Supplementing milk replacer with omega-3 fatty acids from fish oil on immunocompetence and health of Jersey calves. J. Dairy Sci. 91:3488-3500. https://doi .org/10.3168/jds.2008-1017.

Calder, P. C. 2010. Omega-3 fatty acids and inflammatory processes. Nutrients 2:355-374. https://doi.org/10.3390/nu2030355.

Calder, P. C. 2012. Long chain fatty acids and inflammation. Proc. Nutr. Soc. 71:284-289. https://doi.org/10.1017/S0029665112000067.

Calder, P. C. 2017. Omega-3: The good oil. Nutr. Bull. 42:132-140. https://doi.org/10.1111/nbu.12261.

Contreras, G. A., S. A. Mattmiller, W. Raphael, J. C. Gandy, and L. M. Sordillo. 2012. Enhanced n-3 phospholipid content reduces inflammatory responses in bovine endothelial cells. J. Dairy Sci. 95:7137-7150. https://doi.org/10.3168/jds.2012-5729.

Dahl, G. E., S. Tao, and A. P. A. Monteiro. 2016. Effects of lategestation heat stress on immunity and performance of calves. J. Dairy Sci. 99:3193-3198. https://doi.org/10.3168/jds.2015-9990.

Dong, G., S. Liu, Y. Wu, C. Lei, J. Zhou, and S. Zhang. 2011. Dietinduced bacterial immunogens in the gastrointestinal tract of dairy cows: Impacts on immunity and metabolism. Acta Vet. Scand. 53:48. https://doi.org/10.1186/1751-0147-53-48.

Donovan, G. A., I. R. Dohoo, D. M. Montgomery, and F. L. Bennett. 1998. Calf and disease factors affecting growth in female Holstein calves in Florida, USA. Prev. Vet. Med. 33:1-10. https://doi.org/ 10.1016/S0167-5877(97)00059-7.

Eckersall, P. D., and R. Bell. 2010. Acute phase proteins: biomarkers of infection and inflammation in veterinary medicine. Vet. J. 185:23-27. https://doi.org/10.1016/j.tvjl.2010.04.009.

Engle, T. E., J. W. Spears, T. A. Armstrong, C. L. Wright, and J. Odle. 2000. Effects of dietary copper source and concentration on carcass characteristics and lipid and cholesterol metabolism in growing and finishing steers. J. Anim. Sci. 78:1053-1059. https:// doi.org/10.2527/2000.7841053x.

Flaga, J., Ł. Korytkowski, P. Górka, and Z. M. Kowalski. 2019. The effect of docosahexaenoic acid-rich algae supplementation in milk replacer on performance and selected immune system functions in calves. J. Dairy Sci. 102:8862-8873. https://doi.org/10.3168/jds .2018-16189.
Folch, J., M. Lees, and G. H. Sloane Stanley. 1957. A simple method for the isolation and purification of total lipides from animal tissues. J. Biol. Chem. 226:497-509. https://doi.org/10.1016/S0021 -9258(18)64849-5.

Gånheim, C., S. Alenius, and K. Persson Waller. 2007. Acute phase proteins as indicators of calf herd health. Vet. J. 173:645-651. https://doi.org/10.1016/j.tvjl.2006.01.011.

Gelsinger, S. L., A. J. Heinrichs, and C. M. Jones. 2016. A metaanalysis of the effects of preweaned calf nutrition and growth on first-lactation performance. J. Dairy Sci. 99:6206-6214. https:// doi.org/10.3168/jds.2015-10744.

Godden, S. 2008. Colostrum management for dairy calves. Vet. Clin. North Am. Food Anim. Pract. 24:19-39. https://doi.org/10.1016/ j.cvfa.2007.10.005.

Hill, T. M., H. G. Bateman II, J. M. Aldrich Pas, and R. L. Schlotterbeck. 2007. Effects of the feeding rate of high protein calf milk replacers. Prof. Anim. Sci. 23:649-655. https://doi.org/10.15232/ S1080-7446(15)31036-6.

Hill, T. M., M. J. VandeHaar, L. M. Sordillo, D. R. Catherman, G. G. Bateman II, and R. L. Schlotterbeck. 2011. Fatty acid intake alters growth and immunity in milk-fed calves. J. Dairy Sci. 94:39363948. https://doi.org/10.3168/jds.2010-3935.

Jin, J., W. E. Boeglin, and A. R. Brash. 2021. Analysis of 12/15-lipoxygenase metabolism of EPA and DHA with special attention to authentication of docosatrienes. J. Lipid Res. 62:100088. https: //doi.org/10.1016/j.jlr.2021.100088.

Karcher, E. L., T. M. Hill, H. G. Bateman II, R. L. Schlotterbeck, N. Vito, L. M. Sordillo, and M. J. Vandehaar. 2014. Comparison of supplementation of $\mathrm{n}-3$ fatty acids from fish and flax oil on cytokine gene expression and growth of milk-fed Holstein calves. J. Dairy Sci. 97:2329-2337. https://doi.org/10.3168/jds.2013-7160.

Khan, M. A., A. Bach, D. M. Weary, and M. A. G. von Keyserlingk. 2016. Invited review: Transitioning from milk to solid feed in dairy heifers. J. Dairy Sci. 99:885-902. https://doi.org/10.3168/jds.2015 -9975 .

Littell, R. C., P. R. Henry, and C. B. Ammerman. 1998. Statistical analysis of repeated measures data using SAS procedures. J. Anim. Sci. 76:1216-1231. https://doi.org/10.2527/1998.7641216x.

McGuirk, S. M. 2008. Disease management of dairy calves and heifers. Vet. Clin. North Am. Food Anim. Pract. 24:139-153. https://doi .org/10.1016/j.cvfa.2007.10.003.

Melendez, P., R. Ramirez, M. P. Marin, M. Duchens, and P. Pinedo. 2020. Comparison between linseed expeller and canola expeller on concentrate intake and circulating inflammatory mediators in Holstein calves. Anim. Nutr. 6:47-53. https://doi.org/10.1016/j.aninu 2019.11.008.

Monteiro, A. P. A., J. R. Guo, X. S. Weng, B. M. Ahmed, M. J. Hayen, G. E. Dahl, J. K. Bernard, and S. Tao. 2016. Effect of maternal heat stress during the dry period on growth and metabolism of calves. J. Dairy Sci. 99:3896-3907. https://doi.org/10.3168/jds .2015-10699.

Murray, C. F., M. C. Windeyer, T. F. Duffield, D. B. Haley, D. L. Pearl, K. M. Waalderbos, and K. E. Leslie. 2014. Associations of serum haptoglobin in newborn dairy calves with health, growth, and mortality up to 4 months of age. J. Dairy Sci. 97:7844-7855. https://doi.org/10.3168/jds.2014-8465.

NRC (National Research Council). 2001. Nutrient Requirements of Dairy Cattle. 7th rev. ed. National Academies Press.

Omole, O. O., G. Nappert, J. M. Naylor, and G. A. Zello. 2001. Both L- and D-lactate contribute to metabolic acidosis in diarrheic calves. J. Nutr. 131:2128-2131. https://doi.org/10.1093/jn/131.8 2128 .

Opgenorth, J., L. M. Sordillo, J. C. Gandy, and M. J. VandeHaar. 2020b. Colostrum supplementation with n-3 fatty acids does not alter calf outcome on a healthy commercial farm. J. Dairy Sci. 103:11689-11696. https://doi.org/10.3168/jds.2019-18046.

Opgenorth, J., L. M. Sordillo, A. L. Lock, J. C. Gandy, and M. J. VandeHaar. 2020a. Colostrum supplementation with n-3 fatty acids alters plasma polyunsaturated fatty acids and inflammatory mediators in newborn calves. J. Dairy Sci. 103:11676-11688. https: //doi.org/10.3168/jds.2019-18045. 
Orellana Rivas, R. M., G. H. Komori, V. V. Beihling, T. N. Marins, J. K. Bernard, and S. Tao. 2020. Effects of milk replacer feeding levels on performance and metabolism of preweaned dairy calves during summer. J. Dairy Sci. 103:313-324. https://doi.org/10.3168/ jds.2019-17360.

Pecora, F., F. Persico, A. Argentiero, C. Neglia, and S. Esposito. 2020. The role of micronutrients in support of the immune response against viral infections. Nutrients 12:3198. https://doi.org/ 10.3390/nu12103198.

Peña, G., C. Risco, E. Kunihiro, M.-J. Thatcher, and P. J. Pinedo. 2016. Effect of housing type on health and performance of preweaned dairy calves during summer in Florida. J. Dairy Sci. 99:1655-1662. https://doi.org/10.3168/jds.2015-10164.

Shivley, C. B., J. E. Lombard, N. J. Urie, C. A. Kopral, M. Santin T. J. Earleywine, J. D. Olson, and F. B. Garry. 2018. Preweaned heifer management on US dairy operations: Part VI. Factors associated with average daily gain in preweaned dairy heifer calves. J. Dairy Sci. 101:9245-9258. https://doi.org/10.3168/jds.2017-14022.

Sordillo, L. M. 2016. Nutritional strategies to optimize dairy cattle immunity. J. Dairy Sci. 99:4967-4982. https://doi.org/10.3168/jds .2015-10354.

Tao, S., A. P. Monteiro, I. M. Thompson, M. J. Hayen, and G. E. Dahl. 2012. Effect of late-gestation maternal heat stress on growth and immune function of dairy calves. J. Dairy Sci. 95:7128-7136. https://doi.org/10.3168/jds.2012-5697.
Van Amburgh, M. E., F. Soberon, M. J. Meyer, and R. A. Molano. 2019. Symposium review: Integration of postweaning nutrient requirements and supply with composition of growth and mammary development in modern dairy heifers. J. Dairy Sci. 102:3692-3705. https://doi.org/10.3168/jds.2018-15270.

Wang, J., J. Li, F. Wang, J. Xiao, Y. Wang, H. Yang, S. Li, and Z. Cao. 2020. Heat stress on calves and heifers: A review. J. Anim. Sci. Biotechnol. 11:79. https://doi.org/10.1186/s40104-020-00485 $-8$.

Worden, L. C., M. G. Erickson, S. Gramer, C. Tap, C. Ylioja, N. Trottier, C. L. Preseault, M. J. VandeHaar, A. L. Lock, and E. L. Karcher. 2018. Short communication: Decreasing the dietary ratio of n- 6 to n-3 fatty acids increases the n-3 concentration of peripheral blood mononuclear cells in weaned Holstein heifer calves. J. Dairy Sci. 101:1227-1233. https://doi.org/10.3168/jds.2017-12696.

\section{ORCIDS}

P. Melendez 이 https://orcid.org/0000-0002-7217-9244

C. F. Roeschmann (® https://orcid.org/0000-0001-6267-7883

S. Tao $\odot$ https://orcid.org/0000-0002-9447-2994

P. Pinedo $\odot$ https://orcid.org/0000-0001-7111-3377

J. K. Bernard ๑ https://orcid.org/0000-0001-9703-3498 